Nunt. Antiquus, Belo Horizonte, v. 14, n. 1, p. 159-183, 2018

\title{
Cuca, the "Bogeywoman" of Brasil
}

\author{
Cuca, a "papona" do Brasil
}

\author{
Marina Pelluci Duarte Mortoza \\ mpelluci@gmail.com
}

\begin{abstract}
The figure of the bogeyman terrifies children and has been used as an educational resource since Antiquity in Mankind's History. Mythologies around a creature that wanders at night to look for disobedient children are spread all over the Globe. This study will focus on the figure of the Brazilian Bogeyman. Therefore, the Cuca was chosen as the main axis since she is the most popular child-eater of Brazil. She was elevated to the status of literary star by the novel $\mathrm{O}$ Saci (The Saci), by Monteiro Lobato, and to the status of TV star by the series $O$ sitio do pica-pau amarelo (The Yellow Woodpecker Farm), based on the work of the same author. The main objective of this study is to create a simplified history of the evolution of the figure of Cuca. Other "child-eaters" (Greek, Iberian and Brazilian) will be mentioned in a more generic fashion, just to complement the historical-philological evolution of this figure in Brazil. This study is composed of a historical analysis of the development of this monster both in the Iberian Peninsula and in "Tupiniquim Lands", punctuated by small comparisons between Cuca and Lamia only for the sake of investigative curiosity. However, the greatest part of this work will be composed of a philological analysis of the words coco, coca and cuca, a fundamental tool in the comprehension of the historical and social evolution of Cuca in Brazil.
\end{abstract}

Keywords: Coco; Coca; Cuca; Lamia; Bogeyman; Childhood Fears.

Resumo: A figura do "bicho-papão" atemoriza as crianças e serve como recurso educativo desde a Antiguidade na história da Humanidade. Mitologias criadas em torno de uma criatura que vaga pela noite à procura de crianças desobedientes estão espalhadas globo afora. Este estudo vai investigar a figura do papão brasileiro. Portanto, a Cuca foi escolhida como eixo central, pois é a "papona" brasileira mais popular. Ela foi elevada ao status de estrela literária pelo romance infantil $O$ saci, de Monteiro Lobato, 
e de estrela de televisão pela série chamada $O$ sítio do pica-pau amarelo, baseada na obra do mesmo autor. O objetivo principal deste estudo é fazer um histórico evolutivo simplificado da figura da Cuca. Outros "papões", gregos, ibéricos e brasileiros, serão mencionados de uma maneira geral, apenas para complementar a evolução históricofilológica da figura da Cuca no Brasil. Esse estudo é composto de uma análise histórica do desenvolvimento dessa figura na Península Ibérica e em terras tupiniquins, pontuada de pequenas comparações entre a Cuca e a Lâmia somente a título de curiosidade investigativa. Contudo, a maior parte deste estudo é composta de uma análise filológica mais aprofundada das palavras coco, coca e cuca, exame que é fundamental para a compreensão da evolução histórica e social da Cuca no Brasil.

Palavras-chave: Coco, Coca, Cuca, Lâmia, bicho-papão, pavores infantis.

The figure of the bogeyman, a horrific being that wanders around at night and comes to people's houses to get, and eat, disobedient children, has apparently been used as an educational resource since some of the most remote periods in the history of Mankind. In the 4th century BCE Plato, in his Republic, criticized both the lack of limits poets display in their mythical creations and the use mothers did of such threatening myths in order to get their children to behave:

[...] and also do not trick us with a lot of things of the like. And neither the mothers, seduced by them, should frighten their children when they tell the myths in a twisted way, as when they say that some gods wander at night looking like foreigners of many types; in order for them not to incur in blasphemy against the gods, on one side, and at the same time, not to transform the children in complete cowards. (PLATO, Republic, 381e-382a). ${ }^{1}$

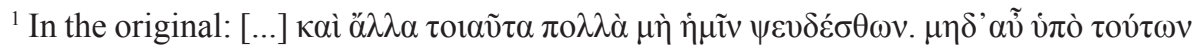

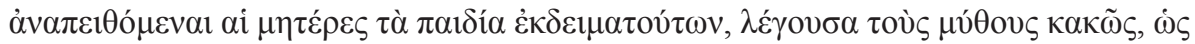

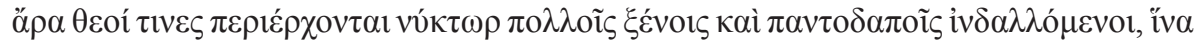

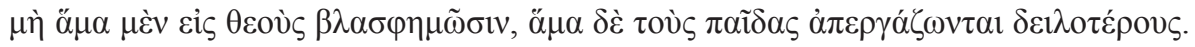
All the translations are mine.
} 
Plato is preaching against the loose invention of the poets and the use some mothers do of such bad creations, both being of little use to a health collectivity. On the same theme Horace, a Roman poet that lived three centuries after Plato, said to his colleagues Pisos in his text The Art of Poetry that ficction cannot do it all:

Let not the fictions that aim to grant pleasure go too far away from reality: let not Fable intend people to believe everything it invents, nor extract alive from the stomach of the Lamia a boy that she had just eaten. (HORACE, The Art of Poetry, 340). ${ }^{2}$

Lamia was one of the bogeymen used in the education of children in both Ancient Greece and Rome, as were also the monstrous beings called Mormo, Gello, Gorgo, among others. ${ }^{3}$ From these ancient periods to nowadays the tradition of using bogeymen as an educational resource did not laid forgotten, on the contrary, it was passed from one generation to the next, and developed a great number of "child eaters" worldwide. ${ }^{4}$ According to Milanez (2011, p. 4), "Undoubtedly, fear here is a technique of disciplinary subjection", 5 the pedagogy of threatening the children so they obey, or learn.

The mythological creature Lamia appears in the Ancient World in many different manners. The first literary register on her can be found in the poet Stesichorus (7th-6th century BCE, cited by a commentator on the Odyssey, as we do not have anything left from the poet himself), and makes reference to a Lamia that would be the mother of the sea monster Scylla, the same creature that devoured six of the companions

\footnotetext{
${ }^{2}$ In the original: "ficta voluptatis causa sint proxima veris: ne quodcumque volet poscat sibi fabula credi neu pransae Lamiae vivum puerum extrahat alvo".

${ }^{3}$ For Gello, check Grimal, 2005, p. 183, and New Pauly, 2005, v. 5, p. 728; for Gorgo check Grimal, 2005, p. 187-188; New Pauly, 2005, v. 5, p. 937-939; LIMC, v. IV ${ }^{1}$, p. 285-330, and v. IV', p. 163-187; for Mormo check Grimal, 2005, p. 318; for lamia, check LIMC v. VI' 1992 , p. 189, and v. $\mathrm{VI}^{2}$, 1992, p. 90-91, Grimal, 2005, p. 265-266 and notes, Graves, 1992, p. 205-206, New Pauly, 2005, p. 181-182.

${ }^{4}$ Check Cascudo, 2010, p. 197-216.

${ }^{5}$ In the original: "Sem dúvida o medo, aqui, é uma técnica de sujeição disciplinar".
} 
of Odysseus on their way back home. ${ }^{6}$ After this mention, Lamia is cited by, in chronological order: Euripides, that puts her as the announcer of the prologue of one of his satyr plays, probably called Lamia (though some researchers say it was a satyr play called Bousiris, ${ }^{7}$ and there is an ongoing debate on this matter); Aristophanes (Peace, 758; Wasps, 1035), that makes a very specific reference to her hermaphroditism when he says she had badly washed testicles; ${ }^{8}$ Aristotle (History of Animals, 540b18), that uses her name to denominate a fish particularly solitary and voracious; Diodorus Siculus (Historical Library, 20.41.3-5), that narrates the story of a beautiful Libyan queen that went mad after loosing all of her children and then decided to have all the newborns of her kingdom executed, and that used to "close her eyes" to the inappropriate behavior of her people when drunk; Horace, above-mentioned; Strabo (Geography, 1.2.8), that also makes reference to the "bogeywoman" Lamia when he affirms that myths should be told to children not only to give them pleasure, but also to drive them away from evil; Pliny the Elder (Natural History, 9.78), that also cites the fish named Lamia by Aristotle; Plutarch (On Being a Busybody, 515f2-516a), that cites the curious capacity the Lamia had to take out her eyes to go to sleep when she wanted to rest in her home; Pausanias (Description of Greece, 10.12.1), who affirms that the first sibyl to profess the oracles of Apollo in Delphi was a daughter of the Libyan queen Lamia with Zeus; Galen (On the Properties of Foodstuffs, 6.727), that also cites the fish Lamia; Apuleius (Metamorphoses, 1.17.5), that puts the word lamia in the mouth of one of his characters to curse

\footnotetext{
${ }^{6}$ PAGE; DAVIES, 1999, $P M G F$, fr. 220. For Cila ( $\left.\Sigma \kappa u ́ \lambda \lambda \eta\right)$, check Grimal, 2005, p. 88-89. Scylla appears in Book XII of the Odyssey, in which she devours six of the companions of Odysseus. All the authors are presented in chronological order, except when some observation is made.

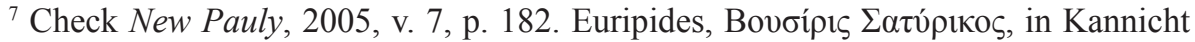

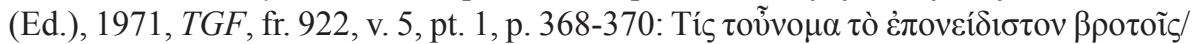

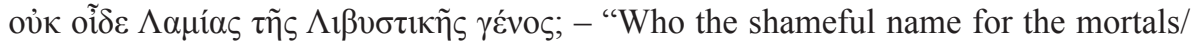
does not know of Lamia of the Libyan race?".

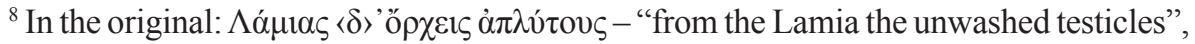

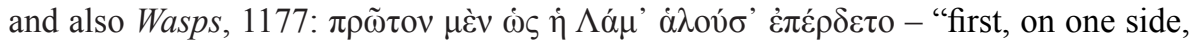
how the Lamia, when being kidnapped, farted".
} 
the witches that peed on him after killing his friend; Philostratus (Life of Apollonius, 4.25), who narrates an episode in the life of the philosopher Apollonius of Tyana in which he unmasks a spectral Lamia (he uses the Greek word $\varphi \alpha \dot{\sigma} \mu \alpha$ to refer to her) that wanted to marry one of the disciples of Demetrius, philosopher of Corinth, just - immediately after the union - to devour him; Opian of Cilicia (Halieutics, 1.370, $5.36 \mathrm{e}$ 5.358), that also tells us about the voracious fish; and finally Antoninus Liberalis (Metamorphoses, 4. 1-7; CIVITA, 1973, v. III, p. 730), that narrates the story on how the Sybaris fountain arose in the same place where the Lamia that inhabited a cave in the whereabouts of Delphi was killed.

However, Lamia's myth did not die in Antiquity. It crossed eras and arrived very much alive in more contemporary times. Byzantine and Medieval authors mention her: Michael of Ephesus, in his commentaries on the Nichomachean Ethics by Aristotle (124 v, 3-9; 169r), and Albertus Magnus, master of Saint Thomas Aquinas, in his De animalibus (5.15; 22.112). In the period of the Romanticism, John Keats composed an extensive poem named Lamia that he published in 1819; and also Edward MacDowell (1860-1908), an American composer, wrote a play for orchestra named Lamia in 1908. Nowadays the Greeks still say Tó

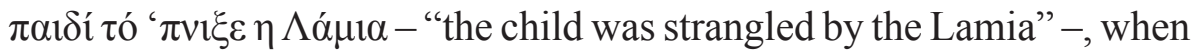
some small kid dies. ${ }^{9}$

In Medieval Age, in the Iberian Folklore, there was a being named Coca, which used to terrify children's minds. Clodio Pérez (1993, p. 6), a specialist on the study of the figure of Coca in the region of Galicia, answers the question - what is the Coca? - in the following manner: "Coca is nothing more than a draconiform processional figure that embodies the Devil". ${ }^{10}$ Pérez affirms that the tradition of Coca has its roots in the Roman rituals of homage to Juno Sospita, in which the young left gifts in the entrances of the caves where it was said that the serpents of this

\footnotetext{
${ }^{9}$ Check New Pauly, 2005, v. 7, p. 181-182; LIMC, v. VI ${ }^{1}$, 1992, p. 189; Silva, 2010, p. 22-23.

${ }^{10}$ In the original: "a coca non é máis que unha figura processional draconiforme que simboliza o Demo".
} 
goddess inhabited, so she could give them a good harvest. On the mythical occurrences of association between the figure of the serpent and the one of the dragon, Pierre Brunel (1997, p. 133) says that it is impossible to number all of them, and this only for the West. He also affirms that both the dragon and the serpent are ambiguous figures: both are associated to Evil, mostly because of the image the Bible made of them (even though there is an episode in which the serpent saves people - Numbers, 21.49.), but they can also be related to ideals of wisdom, representing the "unconstrained impulses of a positive animality" (BRUNEL, 1997, p. 130-131, 133-134). Thus, the two monsters were commonly confounded in popular imagination.

Centuries later, both in Troyes and Metz, in France, as well as in Redondela, Betanzos and Monção, in Galicia, the cocas were a common element of the Corpus Christi processions, and the faithful stuffed their mouths with food. According to Pérez (1993, p. 10), the objective of such actions was "to be in peace with the monster in order to be freed of the danger". ${ }^{11}$ Pérez thinks that the most probable is that the first displacements of the processional dragons happened around the 5 th century CE, under the influence of Saint Mamertus. He was upset with the Romans for their insistence in worshipping the goddess Ceres. Around the 29th of May the Romans would make homage to Ceres with a huge celebration in which many animals were sacrificed, the rites of the Ambarvalia or Ambarula. Saint Mamertus, then, instituted at the same time as the Ambarvalia processions in honor of the Assumption to end once and for all with such pagan rites. In the first day of the celebration a huge image of the dragon would open the procession, with his head and tail standing up high. In the last day the dragon would be the last to enter, with his head and tail down towards the floor, and his defeat was symbolized by the cross, that would open the procession (PÉREZ, 1993, p. 10). Thus, when Pope Urban IV officialized the celebration of Corpus Christi in 1264, and right after that, in 1317, when Pope John XXII added the processions to it, many of the figures of the young Christianity naturally migrated to the newly-established celebration. The

\footnotetext{
${ }^{11}$ In the original: "[...] de poñerse a ben co monstro para así librarse do seu perigo".
} 
coca was thus promptly associated to Christ's defeated enemy. Pérez (1993, p. 13) affirms, "This was to be expected, for while the host was the representation of the Supreme Good, or God, the old Coca could be nothing else than the representation of Supreme Evil, or Satan". " $\mathrm{He}$ cites the French historian Jacques de Vitry to confirm his thesis: "This monster symbolized the Devil: first triumphant, and soon enough beaten (this dragon was the Devil)" (PÉREZ, 1993, p. 11). ${ }^{13}$ Pérez (1993, p. 18) also says "in the New Testament the dragon is already completely identified with the Devil, with the serpent of Genesis". ${ }^{14}$ The dragon was always defeated by a saint that could be Saint George, Saint Martha, Saint Margaret, and Saint Michael the Archangel, or even by many pious men, as in Pontevedra, where the defeaters of the dragon were the sailors of a small ship (PÉREZ, 1993, p. 89). Thus the old Coca was transformed in the dragon of Saint George, and also in the beast that would come tied up, pulled by the rope of Saint Martha or Saint Margaret (PÉREZ, 1993, p. 15 e 90). Concerning the transformation of myths in which a hero fights a monster in the shape of a dragon or serpent, Pérez concludes:

The influence, direct or indirect, of such myths in the legends of Christian saints is easily proved by the case of the warrior named Saint George. It is supposed that the creation of the fight against the dragon dates from the end of the 12th century CE, or from the beginning of the 13th century CE. Some scholars identify it with the Nabataean myth of Tammuz, others are of the opinion that it can come from the Classical myth of Perseus, while the Copts associate Saint George to the

\footnotetext{
${ }^{12}$ In the original: "Era de esperar que sucedese así, porque mentres que a hostia viña a se-la representación do supremo Ben, de Deus; a vella coca non ía ser máis que a do Mal, de Satán".

${ }^{13}$ In the original: "[...] que este monstro simbolizaba o demo, primeiro triunfante e logo vencido (draco iste significat diabolum)".

${ }^{14}$ In the original: "[...] no Novo Testamento o dragón xa está plenamente identificado co demo, coa serpe do Xénesis". Para uma discussão a respeito das associações entre dragão e serpente, veja-se Pérez, 1993, p. 16-24, e notas.
} 
Egyptian God Horus, all of them defeaters of dragons, serpents, crocodiles... (PÉREZ, 1993, p. 29). ${ }^{15}$

As a matter of fact, the Galician author affirms that the oldest register of the presence of the processional Coca in the Corpus Christi celebrations comes from Portugal, from the year 1265. He says that the figure of Saint George was introduced in 1387, according to Padre Francisco da Fonseca, who wrote in the year of 1728 a description of this first procession (PÉREZ, 1993, p. 90). Pérez (p. 90-91) also cites the date of 1400 for the first registers of such tradition in the city of Valencia, in Catalonia: "The Cuca of Saint Margaret and the Cuca of Saint George". ${ }^{16}$

In Spain, Coca was a monster five meters high, made with cardboard paper and canvas: a dragon with a "pachydermic body, cricket legs, a serpent's tail, and a big pair of wings" (CASCUDO, 2010, p. 202). ${ }^{17}$ Pérez affirms that the body form of the Coca is inherited from the medieval plastic, and it varies little in the diverse traditions in which it is present: it is always a being with "the body of a serpent with or without paws (two or four), a high up head with a comb and big toothed maxillary, membranous wings that remind us of bats' wings, and a tail in the shape of the point of an arrow" (1993, p. 7). ${ }^{18}$ According to Pérez (p. 5) the tradition of having cocas in the processions of Corpus Christi was kept till the period between the end of the 18th century and the beginning of the 19th century not only in Galicia and the rest of the

\footnotetext{
${ }^{15}$ In the original: "A influencia, directa ou indirecta, destes mitos nas lendas de santos cristiáns, compróbase doadamente co caso do guerreiro San Xurxo. O engadido da loita co dragón suponse que sexa de finais do século XII ou princípios do XIII, e mentres que uns investigadores apuntan que foi tomado do mito nabateo de Tammuz; outros opinan que puido ser do clásico de Perseo, anque tampoco hai que esquecer que os coptos o vencellan co exipcio Horus, todos eles vencedores de dragóns, serpes, crocodilos...". ${ }^{16}$ In the original: "cuqua de Santa Margalita e la cuqua de Sent Jordi".

${ }^{17}$ In the original: "corpo paquidérmico, patas de grilo, cauda serpentiforme e com um grande par de asas".

${ }^{18}$ In the original: "corpo serpentiforme sen ou con patas (dúas ou catro), cabeza ergueita con crista e grandes fauces dentadas, ás membranosas que lembran as dos morcegos e cola rematada en dardo".
} 
Iberian Peninsula, but also in France, Belgium, Germany, England, and many other European countries.

The word Pérez cites as the first official register of the name coca in Galician is coquetriz, from 1437, meaning simply the processional alligator (1993, p. 93). According to Antenor Nascentes (1932, p. 194, entry côca), the word cuca derives from the Quechuan ${ }^{19}$ cuca or coca, or from the Aymara ${ }^{20}$ coca, 'tree', or still from the Tupi-Guarani ${ }^{21} \operatorname{cog}$, 'to sustain, to feed'. The Latin coccum, cocci (and its cognates) seems little or nothing enlightening, for it denominates a type of grain used to dye cloths in scarlet color, and, as a consequence, also the cloths that were already dyed (FARIA, 2003, p. 200, entry coccum; GLARE, 1994, p. 340, entries coccinatus, coccineus, coccinus, coccio, coccum). However, this Latin word comes from the Greek кóккоร, which was the berry that used to give the scarlet color to cloths; and from it comes the word кóккıио , 'scarlet', and those last two might be the best etymological options for

${ }^{19}$ HOUAISS, 2008, p. 2.358: "Indigenous Language, or belonging to it, spoken even nowadays in the countries of the Andes Mountains, from Chile to Colombia, and especially in Equador and Peru [It was the language spoken in the Ancient Inca Empire]". - "Diz-se de ou língua indígena, ainda hoje falada nos países da cordilheira dos Andes, do Chile à Colômbia, esp. no Equador e Peru [Foi a língua falada no antigo império inca]".

${ }^{20}$ HOUAISS, 2008, p. 128: "1. individual from the Aymara People, Indians from the Peruvian and Bolivian Andes [The Aymaras are formed by approximately 2 million individuals in Bolivia, the south of Peru, and some groups in the north of Chile and of Argentina]; 2. indigenous linguistic family that comprehends all the languages spoken by the Aymaras". - "1. indivíduo dos aimarás, indígenas dos Andes peruanos e bolivianos [Os aimarás compreendem, aproximadamente, dois milhões de indivíduos na Bolívia, Sul do Peru, e alguns grupos ao Norte do Chile e da Argentina]; 2. fam. linguística indígena que compreende todas as línguas faladas pelos aimarás".

${ }^{21}$ HOUAISS, 2008, p. 2.786: "Linguistic Family (Tupi Group) with the most widespread geographical distribution in Brazil, spreading all over 13 states and composed of around 20 living languages, with small internal diferentiation; also in use in the following countries: French Guiana, Venezuela, Colombia, Peru, Bolivia, Paraguay and Argentina". - "Família linguística (tronco tupi) com a maior distribuição geográfica no Brasil, estendendo-se por 13 estados e compreendendo cerca de 20 línguas vivas, com pequena diferenciação interna; tb. em uso nos seguintes países: Guiana Francesa, Venezuela, Colômbia, Peru, Bolívia, Paraguai e Argentina". 
the word coco, which designates the fruit of the coconut tree and that

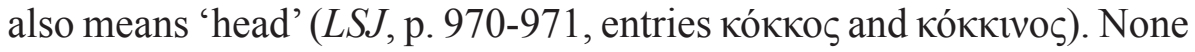
of these words, though, works very well for the derivation of the word coca, unless we can establish associations between the words coca and coco. It is necessary to consider the Latin words derived from coccyx, 'cuckoo', and also from coco/cocere/coquo, 'to cook', as well, including in this consideration the word coquus/cocus, 'the one who cooks, cook', and from it coqua, 'female cook' (GLARE, 1994, p. 341, 443-444). Would it be possible that the $\mathrm{Coca} / \mathrm{Cuca}$ is the 'one that cooks' the children she kidnaps? Such association would make sense in the context in which her legend is normally applied: to get children to behave by frightening them. The great mystery of this folkloric figure is, however, that normally the narratives that involve her do not mention what she does to the children she kidnaps. Some sources say she eats them, but these are veiled consequences, never revealed in their full depth. Nobody says to their children: "the Cuca will come and get you, and cook you and eat you", they keep only the part of "the Cuca will come and get you if you do not behave" to tell the children. This happens perhaps for compassion, perhaps for smoothness. After all, it is desirable to frighten the children a little bit, but only a little bit, since transforming them in complete cowards is out of question, as we have already heard Plato advise.

The Houaiss, one of the most complete dictionaries of the Portuguese Language, enumerates 10 different meanings for the word coca: the already mentioned vegetable meaning (tree, fruit, bush, etc.) and the name by which some small Mediterranean boats were called in Middle Ages among them. However, it is the last meaning that interests us the most: a kind of cloak, or hood, a bogeyman in the metaphorical sense, and also a type of lantern made with a pumpkin in which a face is carved and illuminated by a candle positioned inside the empty pumpkin, an European (British and Iberian) tradition used to frighten people at night (the renowned Jack O'Lantern of the American Halloween HOUAISS, 2008, p. 748, entry coca /ô/). Concerning its etymology, the Houaiss affirms that it is a controversial one, that it might be a feminine variation of coco, or perhaps an extension in the sense of the meaning 
that indicates an spherical object, 'head'. However, it concludes that the use of the word coco to denominate both the fruit of the coconut tree and the head is derived from the meaning of bogeyman or phantom used to scare the children, whose origins remit to the tradition of the head entailed in the pumpkin (HOUAISS, 2008, p. 748, entry coca /ô/, and p. 750, entry ${ }^{1}$ coco $/ \hat{o} /$ ). In Latin, cucullus designates a hood, something to cover the head with, and the word cucurbita is the one that means pumpkin (GLARE, 1994, p. 464-465, entries cucullus, cucullio, cuculliunculum and cucurbita). In the older Brazilian traditions Cuca was a hooded being that scared the children in the processions, and that was named farricoco, or Death (CASCUDO, 2010, p. 203). This tradition also came from Portugal, more specifically from the Algarve region, where

The Portuguese children run in fear because of a scarecrow that follows the Procissão dos Passos (Procession of the Steps), dressed in a long-shrouded tunic, with his head covered in a mask where the two eyes peek through from two holes, and whose only function is to put away the children so they do not disturb the processional march. They say this scarecrow is the Coca. (CASCUDO, 2010, p. 202). ${ }^{22}$

Finally, in the entry cuca, Houaiss concludes the polemic between the three words:

[...] It is important to notice that the entries related to the words cuca, coco /ô/, the ones linked to coca $/ o ́ /$, plus the ones connected with coca $/ \hat{o} /$, have more etymological similarities than their separation in different entries allow us to perceive; coca 'lurking', coca /ô/ 'bogeyman', and cuca interjection 'out!', have semantically specialized values, but they

\footnotetext{
${ }^{22}$ In the original: "as crianças portuguesas correm espavoridas por causa de um espantalho que segue a Procissão dos Passos, vestindo longa túnica amortalhada, coberta a cabeça com uma cágula onde os olhos espreitam por dois buracos, e que se ocupa em afastar os meninos para que não perturbem a marcha processional. Dizem ser este espantalho a Coca".
} 
are intrinsically connected under the meaning of 'amusement, fear, and surprise'; coca 'pumpkin' and cuca 'head' are, per affinity, metaphors of coco 'round fruit' and 'head'; in the same way, all the meanings of coca / $\mathrm{o} /$ are connected to the ones of coco /ô/ and of cuca. (HOUAISS, 2008, p. 883, entry ${ }^{1} \mathrm{cuca}$ )..$^{23}$

Thus, the convergence between the meanings of these three words is clear: there is no doubt they belong to the same semantic field and are used to represent the same things. So much that, in respect to the assimilation among them, Cascudo says, categorically: "coco, coca and cuca are one and the same entity" (2010, p. 201). ${ }^{24}$

On the etymology of the word cuca, which in Brazil is used to describe an old and ugly woman, the Houaiss (2008, p. 883, entry ${ }^{2} \mathrm{cuca}$ ) affirms that the word can come from the Umbundu ${ }^{25} \mathrm{kuka}$ or from the Kimbundu ${ }^{26}$ iakuka, 'old gentleman, old lady'. ${ }^{27}$ Cascudo (1988, p. 265, entry $\mathrm{Cuca}$ ) says: "Cuca is grandfather in $\mathrm{Nbundu}^{28}$ and the gulp that one swallows at once, in the Tupi language. ${ }^{29}$ Thus, the Indigenous

${ }^{23}$ In the original: "[...] note-se que os verbetes relacionados com os significantes $c u c a$, coco /ô/, os enlaçados com coca /ó/ e mais o conexo com coca /ô/ têm mais semelhanças etimológicas do que o deixa entender sua separação nas entradas; coca 'à espreita', coca /ô/ 'papão' e cuca interj. 'fora', têm valores semanticamente especializados, mas intrinsecamente conexos sob 'espanto, medo e surpresa'; coca 'abóbora' e cuca 'cabeça' são por afinidade, como metáfora de coco 'fruto redondo' por 'cabeça'; do mesmo modo, todas as acep. de coca /ô/ ligam-se às de coco /ô/ e de cuca".

${ }^{24}$ In the original: "coco, $\operatorname{coc} a$ e cuca são uma e a mesma entidade".

${ }^{25}$ Umbundu is a "Bantu language spoken by the Ovimbundus, inhabitants of the meridional and central zones of Angola [It comprises the languages Amboim, Biene, Bailundu, Sambu, Huambe, Galangue, Nganda and Caconda]" - "língua banta falada pelos ovimbundos, habitantes das zonas meridional e central de Angola [Compreende as línguas amboim, biene, bailundo, sambo, huambe, galangue, nganda e caconda]". (HOUAISS, 2008, p. 2.803).

${ }^{26}$ Kimbundu is a "language of the Batu family, spoken in Angola by the Ambundus" "língua da família banta, falada em Angola pelos ambundos" (HOUAISS, 2008, p. 2.360).

${ }^{27}$ In the original: "velho, velha".

${ }^{28}$ Another denomination of Umbundu.

${ }^{29}$ HOUAISS, 2008, p. 2.786: "Linguistic Group that comprises, in Brazil, ten living families, distributed by 14 states; it is also spread to the following countries: French 
and African elements contribute for the dispersion of the myth in the characteristic elements". ${ }^{30}$

In the Brazilian folklore, then, the mythologies of at least three very diverse traditions (Indigenous, African and Iberian), were mixed and resulted in something new: the Cuca was transformed in an old woman with long blond disheveled hair and an alligator-like body. Pérez's book offers a light for the reason of the association with the alligator by citing Padre Sarmiento's explanation of the word Tarasca:

In Galicia, specially in Pontevedra, it is not called 'Tarasca', but 'Coca' and this is the proper name to what it represents in the procession of the Corpus [...] The head of the Coca of Pontevedra is not so much as that of a serpent, but as that of a 'cocatrix', the crocodile and by consequence, of the Leviathan that Christ defeated. (CANTÓN, 1959, apud PÉREZ, 1993, p. 7). ${ }^{31}$

Pérez also affirms:

There is no doubt that the name of this symbolic monster comes from the Medieval Latin cocatrix, and that this word comes from the Latin crocodilus (the crocodile), that already in the middle of the 15th century AD (1441) was only used in apocope in writing texts, having only its first syllables preserved

Guiana, Venezuela, Colombia, Peru, Bolivia, Paraguay and Argentina". - "Tronco linguístico que compreende, no Brasil, dez famílias vivas, distribuídas por 14 estados; estende-se tb. pelos seguintes países: Guiana Francesa, Venezuela, Colômbia, Peru, Bolívia, Paraguai e Argentina".

${ }^{30}$ In the original: "cuca é avô em nbundo e o trago, que se engole de uma vez, no idioma tupi Assim, os elementos indígenas e africanos concorrem para a dispersão do mito nos elementos característicos".

${ }^{31}$ In the original: “en Galicia, en especial en Pontevedra, non se chama 'Tarasca' senón 'Coca' e é nome propio para o que representa na procesión do Corpus [...] A cabeza da Coca de Pontevedra non tanto é de serpe como de 'cocatrix', o crocodilo e, por conseguinte, o Leviathán que Cristo venceu". 
and loosing the last one: coqua and qoqa. (PÉREZ, 1993, p. 94). ${ }^{32}$

The Galician author thus is considering that such origins can be applied to both the Galician word coca and the Catalan word cuca. He finally cites the definition of coca in the Dicionário de autoridades (Dictionary of Authorities) of Madrid: "Coca. In some parts of the world like in Galicia and Mancha they thus name the one that is more commonly known as Tarasca: she is a figure of a serpent that in the day of Corpus they put in the procession together with the giants" (Diccionario de la Lengua Castellana..., 1729, p. 387, citado por PÉREZ, 1993, p. 95). ${ }^{33}$ The Houaiss enumerates six meanings for the word tarasca. It is worth to cite three of them that turned to be more interesting for the reflections on this paper: "Monstrous animal that inhabited the margins of the river Rhône"; "deformed body, aberration"; "irascible and ugly woman". The etymology is also explained by the Houaiss (2008, p. 2.673, verbete tarasca): it is a French word - tarasque (1655) - that came from the Provençal tarasco (1369), "fabulous animal, a kind of dragon from the Provençal legends of the topos Tarascon, a city in the south of France". ${ }^{34}$ Pérez also cites the suggestion of the Dicionário de autoridades, from Madrid, from 1737: "Tarasca is taken from the Greek verb Theracca, which means 'to frighten', because it scares and terrifies the children" (Diccionario de la Lengua Castellana..., 1729, VI, p. 227, citado por PÉREZ 1993, p. 97). ${ }^{35}$ The Greek verb cited can only be $\theta \eta \rho \alpha ́ \omega$, and the closest form of the one cited is that of the Perfect, $\tau \varepsilon \theta \eta \dot{\rho} \rho \alpha \alpha$, which

\footnotetext{
${ }^{32}$ In the original: "É indubitable que ó simbólico monstro vénlle o nome do baixo latín cocatrix, e este do latín crocodilus (o crocodilo), que xa a meados do século XV (1441) se usaba na escrita apocopado, facendo uso só das súas primeiras sílabas e perdéndose a última: coqa e qoqa".

${ }^{33}$ In the original: "Coca. En algunas partes, como es en Galicia y la Mancha, llaman assi a la que comunmente se llama Tarasca: que es una figura de serpiente, que el día del Corpus con los Gigantes sacan en la processión".

${ }^{34}$ In the original: "animal fabuloso, espécie de dragão das lendas provençais do top. Tarascon, cidade do sul da França".

${ }^{35}$ In the original: "Tarasca es voz tomada del verbo Griego Theracca, que significa amedrentar, porque espanta, y amedrenta a los muchachos".
} 
means 'to hunt, chase, search for, catch, capture'. This verb comes from the word $\theta \dot{\eta} \rho, \theta \eta \rho$ ó $\varsigma$, 'beast, monster' (LSJ, 1996, p. 799). The semantic field of 'monstrous, and chase' is kept.

Cascudo defined cuca as a "Feminine bogeyman, a shapeless phantom, vague and threatening, devouring children, bogeywoman" (1988, p. 265, entry Cuca) and affirmed categorically: "Coca and cuca are synonyms of fears or insatiable bogeywomen" (p. 201-207, entries Coca and cuca). ${ }^{36}$ Concerning the shape of Cuca, Milanez agrees with Cascudo that she is shapeless in these lullabies:

Cuca does not have an established form, she is merely designated by a name [...]. An incorporeous body, a name carried of memories of evils, Cuca becomes the representation of punishment in its highest degree, for it corresponds to the size of the fear that each one creates according to their own anxieties and fears. (MILANEZ, 2011, p. 4). ${ }^{37}$

In other of his books he defined the Cuca as a "very old, ugly and disheveled being that shows up in the middle of the night to take away the restless, talkative and sleepless children" (CASCUDO, 2010, p. 200). ${ }^{38}$ He also described her (p. 200): "An old woman, very old and wrinkled, with very white hair, very skinny and with a hump on her back, always eager for the children that do not want to go to bed early and that make a lot of noise". ${ }^{39}$ Cascudo completed saying that she is like a nocturne

${ }^{36}$ In the original: "papão feminino, um fantasma informe, entre vago, ameaçador, devorando as crianças, papona"; and "A coca e a cuca são sinônimos de pavores ou de paponas insaciáveis", respectively.

${ }^{37}$ In the original: "A Cuca não tem uma forma estabelecida, é apenas designada por um nome [...]. Corpo incorpóreo, nome carregado de memórias de maldades, a Cuca se torna a representação da punição em seu mais alto grau, pois corresponde ao tamanho do medo que cada um cria de acordo com seus próprios anseios e temores".

${ }^{38}$ In the original: "um ente muito velho, feio, desgrenhado, que aparece durante a noite para levar consigo os meninos inquietos, insones ou faladores".

${ }^{39}$ In the original: "uma velha, bem velha, enrugada, de cabelos brancos, magríssima, corcunda e sempre ávida pelas crianças que não querem dormir cedo e fazem barulho".

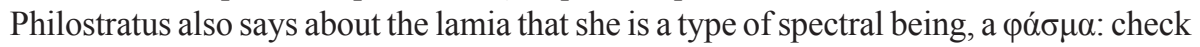


ghost, and that she is part of the folklore of the entire Brazil, and appears everywhere in lullabies.

Yes, for as strange as it seems, the Cuca is a common character of lullabies in Brazil. In the southeast state of Minas Gerais (General Mines) there is a very popular one that says: "Nana, neném,/ que a Cuca vem pegar/ papai foi pra roça,/ mamãe foi passear (Sleep, little baby,/ Cuca will come to get you/ dad's gone to the farm/ and mommy went to take a walk)", and it has many variations. Cascudo registered many of these folkloric songs, like "Durma, meu benzinho,/ que a cuca j'ei vem (Sleep, my little honey,/ 'cause Cuca is coming)".

There are three lullabies, however, that come from two different places and that keep the same essence. Cascudo cites them as being collected by a researcher named Gonçalves Viana in his book Palestras filológicas (Philological Talks). The first one is a popular Portuguese "quadrinha" 40 that says: "Vai-te papão, vai-te, embora/ de cima desse telhado,/ deixa dormir o menino/ um soninho descansado (Go away Bogeyman, go away/ from over this roof/ allow the boy to sleep/ his resting little sleep)"; the second song is a popular quadrinha from the state of Minas Gerais that thus says: "Olha o negro velho/ em cima do telhado,/ Ele está dizendo,/ quer o menino assado (Look at the old black $\mathrm{man} / \mathrm{up}$ there on the roof/ he is saying to us/ he wants the boy roasted)"; and finally the third one, also from Minas Gerais: "Vai-te coca, sai, daqui/ para cima do telhado,/ deixa dormir o menino/ o seu sono sossegado (Go away Coca, leave this place/ to the top of the roof/ let the little boy sleep/ his sleep in peace)". ${ }^{41}$ The most interesting part of this discussion is to notice that the three different songs display an meaningful approximation

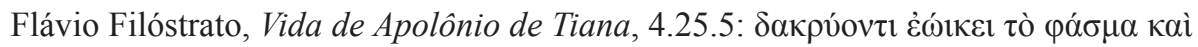

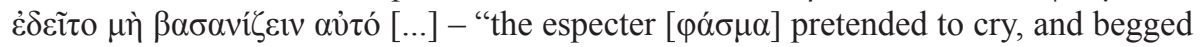
not to be tortured".

${ }^{40}$ The Portuguese "quadrinhas" or "trovas" were a very popular form of rhymed folkloric song ("popular ditty or verses, ding dong", according to Michaelis, or a ballad), composed of four verses of seven syllables each, used normally for expressing challenges, riddles and popular proverbs. $<\mathrm{http}$ ://michaelis.uol.com.br/moderno-ingles/ busca/portugues-ingles-moderno/quadrinha/ $>$.

${ }^{41}$ Check Cascudo, 1988, p. 265, entry Cuca; and also Cascudo, 2010, p. 200-201. 
of their main characters: it is clear that all the three evil characters, the bogeyman, the coca and the old black man are similar entities.

The characters above also share this similarity with the main character of another quadrinha cited by Pérez, which he affirms that to this day is sung by the boys in Portugal:

Vai-te coca, vai-te coca/ lá de cima do loureiro,/ deixa dormir o menino/ o seu soninho primeiro./Vai-te coca, vai-te coca,/ para cima do telhado,/ deixa dormir o menino/ um soninho descansado. (PÉREZ, 1993, p. 147). ${ }^{42}$

This song is identical to the other three. It offers us perhaps a good proof that the tradition of the Iberian figure of the bogeyman suffered alterations and was adopted by the Brazilian folklore in more than one of its legends, like the story of the old black man from Minas Gerais (preto velho mineiro), the old man that carries a bag (velho do saco), and the Tutu-Beast (bicho-tutu) (CASCUDO, 2010, p.197-199). In fact, as Cascudo (1988, p. 265, entry Cuca) points out, the figure of the Iberian Coca had practically disappeared from Brazil when his dictionary was first published in 1954: "Nowadays the presence of the Cuca is infinitely superior to the presence of the semi-disappeared Coca". ${ }^{43}$

The work of a well-known Brazilian writer was fundamental for this definition of the image of the Cuca within the Brazilian children's imagination: Monteiro Lobato was the first writer to register Cuca as the great antagonist in a literary work. ${ }^{44} \mathrm{It}$ is Cuca who terrifies his characters Narizinho (Little Nose) and her cousin Pedrinho (Little Peter) in the story

\footnotetext{
42 "Go away Coca, go away / from up the laurel tree / let the boy sleep / first his little sleep / Go away, Coca, go away, / to up above the roof / let the little boy sleep / his little sleep in peace".

${ }^{43}$ In the original: "Atualmente a presença da cuca é infinitamente superior à coca semidesaparecida".

${ }^{44}$ To know more about Monteiro Lobato's work, check Lacerda, 2008, and the bibliography he suggests.
} 
named O Saci (The Saci ${ }^{45}$ ) from 1921. Lobato is considered the "father" of the Brazilian children's literature. ${ }^{46}$ It was through his work that the literature written especially for kids became really Brazilian, and not a mere reproduction of European fables. Like Bakhtin does to Doistoievsky, Lacerda considers Lobato's work as a "melting pot of cultural references, a carnival-style literature":

[...] we can observe that Lobato's literature positions itself far away from the heroic-epic-warlike model that was typical of the previous phase (of the Brazilian Literature), and approaches a more satyric tone characterized by a miscellany of characters coming from different traditions and repertoires that was, till then, unknown in Children's Literature, which remits us to the formulations of Bakhtin about 'carnivalesque literature' on his Problems of Dostoevsky's Poetics. (LACERDA, 2008, p. 50). ${ }^{47}$

Narizinho and Pedrinho are two cousins that always spend their vacations in the farmland of their grandma, Dona Benta (Lady Goodness).

\footnotetext{
${ }^{45}$ The Saci is a very popular character of the Brazilian folklore. He is normally portrayed as a black boy that wears a red hat and red small shorts, and constantly smokes a pipe. He moves in jumps for he has only one leg (he lost the other in a Capoeira fight), and he is commonly found in small wind swirls. Generally speaking he is not a dangerous character, and his intentions are just to take the kids to perform tricks. His tricks include twisting the manes and tails of animals, inverting the places of things (like putting salt in the sugar pot and sugar in the salt pot and ruining the work of the cooks), confounding travelers during the night, etc. He is the result of a mix of the Indigenous, African and European Classical traditions, as most of the figures in the Brazilian Folklore.

${ }^{46}$ Check Lacerda, 2008, p. 48, citing Marisa Lajolo, that affirms: "Monteiro Lobato inaugurates the Brazilian children's literature" - "Monteiro Lobato inaugura a literatura infantil brasileira".

${ }^{47}$ In the original: "[...] observamos que a obra infantil de Lobato se distancia do modelo heróico, épico, bélico, marcante no ciclo anterior, e se aproxima de um tom satírico, caracterizado por uma miscelânea, até então inédita na literatura infantil, de personagens oriundos de tradições e repertórios diferentes, o que nos remete às formulações de Bakhtin sobre a 'literatura carnavalizada', expostas em Problemas da poética de Dostoiévski”.
} 
However, the little farm is not only made of wonders and also offers some dangers, after all, the Cuca lurks nearby. In this story, though, she will show up only in the end, when in a certain part of the narrative Narizinho is found missing, and Pedrinho and his friend, the Saci of the title of the story, will go looking for her:

- Yes. Narizinho was taken by Cuca. I found out the trail of the horrendous witch close to the corral's gate. We have to go to the cave where she lives to find out what's going on.

- But if the Cuca is powerful like you say, what can we do? (LOBATO, 2007, p. 59). ${ }^{48}$

The Cuca lives in a cave, just like the Greek Lamia. Pedrinho and the Saci are in real trouble for they need to save Narizinho from the Cuca's claws. They arrive at the mentioned cave, disguise as bushes, and enter. Inside they find the Cuca:

Suddenly, when they finished a curve, they saw there in a corner the queen. She was sitting in front of a fire pit, and the luminosity of the flames allowed the "bushes" to see her awful face in all its ugliness. What a monster! She had the face of an alligator and claws in her fingers like hawks do. Concerning her age, she was probably more than 3 thousand years. She was as old as Time itself. (LOBATO, 2007, p. 61). ${ }^{49}$

\footnotetext{
${ }^{48}$ In the original:

“-Sim. Narizinho foi raptada pela Cuca. Descobri o rastro da horrenda bruxa perto da porteira. Temos de ir à caverna onde mora a Cuca e ver o que há.

- Mas se a Cuca é poderosa como você diz que poderemos fazer?"

${ }^{49}$ In the original: "Súbito, ao dobrarem uma curva, viram lá num canto a rainha. Estava sentada diante de uma fogueira, de modo que a claridade das chamas permitia que as 'folhagens' lhe vissem a carantonha em toda a sua horrível figura. Que bicha! Tinha cara de jacaré e garras nos dedos como os gaviões. Quanto à idade, devia andar para mais de 3 mil anos. Era velha como o Tempo".
} 
The description of the cuca is according to the Iberian tradition of the crocodile but as in Brazil there are no crocodiles, the witch was associated to the image of the alligator, a much more common animal in the Brazilian lands. Cuca also only slept one night every seven years, what highlights even more her non-human character:

- We are very lucky - whispered the Saci in the ear of the boy. - Cuca only sleeps one night every seven years, and we arrived exactly in one of those nights.

- How do you know? - Asked Pedrinho with his limitless curiosity.

The Saci got furious and threatened him, that if he continued to ask such questions he would leave him there alone to be devoured by the monster. (LOBATO, 2007, p. 62). ${ }^{50}$

The Cuca then does not sleep much and devours children. Very similar habits to the habits that some of the sources of the myth of the Greek Lamia ascribe to her as well.

From the adventures of Pedrinho and Narizinho movies and TV series were created, and the figure of the Cuca became even more popular in the minds of the Brazilian children, and even of the adults. The first movie made from the book $\mathrm{O}$ Saci is from 1951, and in it the Cuca was just a very old lady dressed in dirty ragged clothes. ${ }^{51}$ The first adaptation for television was made by TV Tupi, from 1953 to 1962. In

50 - Estamos de sorte - disse o Saci ao ouvido do menino. - A Cuca só dorme uma noite cada sete anos e chegamos justamente numa dessas noites.

- Como sabe? - Indagou Pedrinho cuja curiosidade não tinha limites. O Saci danou e ameaçou-o, se continuasse com tais perguntas, de deixá-lo ali sozinho para ser devorado pelo monstro".

${ }^{51}$ Check <www.sitio.globo.com $>$; and also $<$ pt.wikipedia.org/wiki/S\%C3\%ADtio_do_ Picapau_Amarelo $>$ and $<$ pt.wikipedia.org/wiki/S\%C3\%ADtio_do_Picapau_Amarelo_ (série_animada) $>$; check also the article by Keila Jimenez in the newspaper Folha de S. Paulo (São Paulo's Sheet) from 13 mar. 2011. The online version is available to all at <www1.folha.uol.com.br/ilustrada/887114-globo-ressuscita-sitio-do-picapauamarelo-como-animacao.shtml $>$. 
1964 there was an attempt to recreate the series in TV Cultura. It lasted only for six months. From 1967 to 1969 the same program was shown by TV Bandeirantes.

Finally, in 1977 the famous O Sitio do Picapau Amarelo (Yellow Woodpecker Farm) started to be shown. It was a compilation of the works of Monteiro Lobato, bringing to the children the adventures of Narizinho and Pedrinho. It was produced, released and exported by the other Portuguese-speaking countries in the world by Rede Globo, one of the biggest TV conglomerates in Brazil. The series was on air until 1986 and displayed the adventures of the two kids in the farmland of their grandma, which the children followed up eagerly (I was one of them). Cuca, an alligator-woman with blond hair, was the great antagonist, the evil witch of the stories. Rede Globo exhibited, from 2001 to 2007, a new version of the adventures. Since 2008, Canal Futura is reprising all these adventures. In 2012 Rede Globo, associated to the Mixer Productions, started to exhibit the animated version of the adventures, and they even have their own site. The animated series has been exhibited by the channel Cartoon Network to Latin America since 2012. Since 2015, the channel Boomerang started to show the animated series to the world. The image of the Cuca in the series suffered many modifications throughout the years, but she was always associated to witchcraft and the kidnapping of children, and she kept her alligator-like body in almost all the versions.

It is possible to conclude, from all the circumstances evaluated in this paper, that many similarities between Coco, Coca, Cuca and Lamia exist, even though they are not markedly highlighted. The main objective of this paper was to try to verify the existence of such similarities and in that it succeeded. However, to affirm that the myth of the Greek monster Lamia influenced the establishment of a Brazilian monster called Cuca, after all this medieval trajectory in the Iberian Peninsula, and the arrival in a country with so many folkloric traditions being mixed together, is still far away from being possible. Centuries of History lay between Lamia and Cuca, and an impossible-to-count number of Folkloric traditions that were mixed together in the caldron of cultures that formed Brazil. Moreover, even to make an attempt to chase the original "bogeymanic" figure that developed into the Iberians Coca and Coco is a hard path to trail. All those 
childhood monsters belong to a well-established oral tradition that is part of Human Folklore for millennia now. To find the associations made in the centuries of evolution of such stories in the Human imaginary is quite impossible, let alone try to find an original Boogey figure that belonged to the first times of storytelling. Thus, frustrations apart, this paper can only conclude that the Iberian Boogey figures influenced the formation of the Brazilian ones, and that these Boogey figures might have been influenced by the Boogey figures from Ancient Times. More than that, for now, it is not possible to affirm.

\section{Sites to see some useful images}

$<$ http://www.mundonovelas.com.br/2010/10/sitio-do-picapau-amarelovamos-recordar.html>

$<$ http://www.mundonovelas.com.br/2010/10/sitio-do-picapau-amarelovamos-recordar.html>

$<$ http://blogdositiodopicapauamarelo.blogspot.com.br/2010/08/cuca2005-2006.html>

$<$ http://obviousmag.org/archives/2005/03/sitio_do_pica_p_1.html>

$<$ http://turmadopicapauamarelo.blogspot.com.br>

$<$ http://www.cantinhodecrianca.com.br/site/conteudo/s\%C3\%ADtio-dopicapau-amarelo-em-vers $\% \mathrm{C} 3 \% \mathrm{~A} 30$-animada-estreia-dia-7>

$<$ http://telinhadatv.wordpress.com/tag/emilia $>$

$<$ http://www.tnaudiencia.com.br/2012/03/sitio-do-picapau-amarelodesenho_10.html $>$

$<$ http://ogalaico.blogspot.com.br/2009/06/coca-de-moncao.html>

$<$ http://8ou80foto.com/2012/02/11/minhofesta-da-coca-em-moncao>

$<$ http://www.cecmundorural.com.br/?tag=cuca $>$

$<$ http://iagomamapapairia.blogspot.com.br/2012/06/festa-da-coca-deredondela.html >

$<$ http://en.wikipedia.org/wiki/File:Brooklyn_Museum___Here_Comes the_Bogey-Man_(Que_viene_el_Coco)_-_Francisco_de_Goya_y_ Lucientes_crop.jpg> 
$<$ http://www.enriquedans.com/2006/04/estado-policial.html $>$

$<$ http://viajeaqui.abril.com.br/materias/procissao-do-fogareu-2012semana-santa-goias-velho\#6>-é uma procissão em Goiás Velho durante a Semana Santa.

$<$ http://www.aletria.com.br/pagina.asp?area $=16 \&$ secao $=15 \&$ site $=1 \&$ tp $=22 \&$ col $=11 \&$ click $=1136 \&$ id $=520>$

$<$ http://blog.mundodositio.globo.com/2011/11/10/sera-que-a-cucatomou-jeito $>$

$<$ http://revistaquem.globo.com/Revista/Quem/0,,ERT212918-8224,00. html>

$<$ http://www.fnac.com.br/as-melhores-historias-em-quadrinhos-da-cucaFNAC,,kids-144-2162.html $>$

\section{References}

ACKERMANN, H. C.; GISLER, J.-R.; KAHIL, L. (Ed.). Lexicon Iconographicum Mythologiae Classicae (LIMC). Zürich: Artemis, 19861992. v. III' ${ }^{1}, \mathrm{III}^{2}, \mathrm{IV}^{1}, \mathrm{IV}^{2}, \mathrm{VI}^{1}$ e $\mathrm{VI}^{2}$.

ANTONINUS LIBERALIS. Les metamorphoses. Texte établi, traduit et commenté par Manolis Papathomopoulos. Paris: Les Belles Lettres, 1968. APULÉE. Les metamorphoses. Texte établi par D. S. Robertson et traduit par Paul Vallette. Paris: Les Belles Lettres, 1956. t. I (Livres I-III).

APULEIO. O burro de ouro. Tradução do latim e introdução de Delfim Leão. Lisboa: Livros Cotovia e Delfim Leão, 2007.

BRANDÃO, R. de O. (Org.); ARISTÓTELES; HORACIO; LONGINO. A poética clássica: Aristóteles, Horácio, Longino. Tradução direta do grego e do latim de Jaime Bruna São Paulo: Cultrix, 2005.

CANCIK, H.; SCHNEIDER, H. (Ed.). New Pauly: Brill's Encyclopaedia of The Ancient World. Leiden; Boston: Brill, 2005. v. 6-7.

CASCUDO, L. da C. Antologia do folclore brasileiro. São Paulo: Livraria Martins, 1956.

CASCUDO, L. da C. Dicionário do folclore brasileiro. Belo Horizonte: Itatiaia; São Paulo: Editora da Universidade de São Paulo, 1988. 
CASCUDO, L. da C. Geografia dos mitos brasileiros. São Paulo: Global, 2010.

CIVITA, V. (Ed.). Mitologia. São Paulo: Abril Cultural, 1973.

DIODORI. Bibliotheca Historica. Post I. Bekker et L. Dindorf recognovit C. TH. Fisher. Stuttgart: Teubner, 1985.

FARIA, E. Dicionário latino-português. Belo Horizonte: Garnier, 2003.

FORMAN, H. B. The Poetical Works of John Keats. Edited with an introduction and textual notes by H. Buxton Forman. Oxford: Oxford University Press, 1908.

GALENO, C. A natureza e virtude dos alimentos. Tradução de Luigi Castagnola e Carolina M. Albanese. Curitiba: UFPR, 1992.

GLARE, P. G. W. Oxford Latin Dictionary. Oxford: Oxford University Press, 1994.

GRAVES, R. The Greek Myths. London: Penguin Books, 1992.

GRIMAL, P. Dicionário da mitologia grega e romana. 5. ed. Tradução de Victor Jabouille. Rio de Janeiro: Bertrand Brasil, 2005.

HOUAISS, A. Grande dicionário Houaiss da língua portuguesa. Rio de Janeiro: Objetiva, 2008.

KANNICHT, R. (Ed.). Tragicorum Graecorum Fragmenta (TGF). Göttingen: Vandenhoeck \& Ruprecht, 1971. v. 5, pt. 1.

LIDDELL, H. G.; SCOTT, R.; JONES, H. S. (Ed.). A Greek-English Lexicon (LSJ). Oxford: Clarendon Press, 1996.

LACERDA, V. A. Um mergulho na Hélade: mitologia e civilização grega na literatura infantil de Monteiro Lobato. 2008. 164 f. Dissertação (Mestrado em Estudos Literários) - Faculdade de Letras, Universidade Federal de Minas Gerais, Belo Horizonte, 2008.

LE FANU, S. Carmilla, a vampira de Karstein. Tradução de José Roberto O'Shea. Introdução de Alexander M. da Silva. São Paulo: Hedra, 2010.

LOBATO, M. O Saci. São Paulo: Globo, 2007.

MEGAS, G. A. Folktales of Greece. Translated by Helen Colaclides. Foreword by Richard M. Dorson. Chicago; London: The University of Chicago Press, 1970. 
MILANEZ, N. A Cuca vai pegar! Medidas do corpo no caldeirão discursivo do medo. Acta Scientiarum. Language and Culture, Maringá, v. 33, n. 2, p. 251-258, 2011.

NASCENTES, A. Dicionário etimológico da língua portuguesa. Rio de Janeiro: Francisco Alves, 1932.

OPPIAN, COLLUTHUS, TRYPHIODORUS. Translated by A. W. Mair. Cambridge: Harvard University Press, 1928.

PAGE, D. L.; DAVIES, M. (Ed.). Poetarum Melicorum Graecorum Fragmenta (PMGF). Oxford: Oxford University Press, 1999. v. I.

PAUSANIAS. Description of Greece: Books VIII.22-X. Translated by W. H. S. Jones. Cambridge; London: Harvard University Press, 1935.

PÉREZ, C. G. A coca e o mito do dragon. Vigo: Ir Indo, 1993.

PHILOSTRATUS. The Life of Apollonius of Tyana. Edited and translated by Christopher P. Jones. Cambridge; London: Harvard University Press, 2005. Books I-IV.

PLATÃO. A república. Tradução de Carlos Alberto Nunes. Belém: EDUFPA, 2000.

PLINE L'ANCIEN. Histoire naturelle. Texte établi, traduit et commenté par E. de Saint-Denis. Paris: Les Belles Lettres, 1955. Livre IX.

PLUTARCH. Moralia. Translated by W. C. Helmbold. Cambridge; London: Harvard University Press, 2005. Volume VI.

SILVA, A. M. da. Introdução. In : LE FANU, S. Carmilla, a vampira de Karnstein. Tradução de José Roberto O'Shea. Introdução de Alexander M. da Silva. São Paulo: Hedra, 2010. p. 9-37.

STRABON. Geographie. Texte établi et traduit par Germaine Aujac. Paris: Les Belles Lettres, 1969. t. I, $1^{\text {re }}$ partie.

Recebido em: 30 de abril de 2018. Aprovado em: 15 de junho de 2018. 